University of Nebraska - Lincoln

DigitalCommons@University of Nebraska - Lincoln

Papers in the Earth and Atmospheric Sciences Earth and Atmospheric Sciences, Department

1999

\title{
Lethal Sandslides from Eolian Dunes
}

David B. Loope

University of Nebraska, Lincoln, dloope1@unl.edu

Joseph A. Mason

University of Nebraska, Lincoln

Lowell Dingus

American Museum of Natural History, Idingus@earthlink.net

Follow this and additional works at: https://digitalcommons.unl.edu/geosciencefacpub

Part of the Earth Sciences Commons

Loope, David B.; Mason, Joseph A.; and Dingus, Lowell, "Lethal Sandslides from Eolian Dunes" (1999). Papers in the Earth and Atmospheric Sciences. 210.

https://digitalcommons.unl.edu/geosciencefacpub/210

This Article is brought to you for free and open access by the Earth and Atmospheric Sciences, Department of at DigitalCommons@University of Nebraska - Lincoln. It has been accepted for inclusion in Papers in the Earth and Atmospheric Sciences by an authorized administrator of DigitalCommons@University of Nebraska - Lincoln. 


\title{
GEOLOGICAL NOTES \\ Lethal Sandslides from Eolian Dunes
}

\author{
David B. Loope, Joseph A. Mason, ${ }^{1}$ and Lowell Dingus ${ }^{2}$ \\ Department of Geosciences, University of Nebraska, Lincoln, Nebraska 68588-0340, U.S.A. \\ (e-mail: dloope1@unl.edu)
}

\begin{abstract}
A B S T R A C T
Fossil vertebrates entombed within the Upper Cretaceous Djadokhta Formation of southern Mongolia bear testimony to a heretofore unknown geologic phenomenon: mass wasting of eolian dunes during heavy rainstorms. Evaporation of shallow-penetrating rainwater led to progressive calcite accumulation in a thin layer of sand about $0.5 \mathrm{~m}$ below the surface of dune lee slopes. During rare heavy rainstorms, a perched water table developed at the top of calcitic zones. Positive pore water pressure led to translational slides and fast-moving sediment gravity flows that overwhelmed animals on the lee slopes of large dunes and in interdune areas.
\end{abstract}

\section{Introduction}

The 75-m.yr.-old redbeds of Central Asia's Djadokhta Formation have yielded many of the bestpreserved Mesozoic vertebrate fossils ever discovered. At a single, small site-Ukhaa Tolgod in southern Mongolia (fig. 1)-paleontologists have unearthed more than 1000 skeletons and skulls of 20 species of mammals and reptiles since 1993 (Dashzeveg et al. 1995). In situ fossils are typically fully articulated and show no evidence of scavenging. Thick crossbeds that were deposited by eolian dunes and accumulated calcite while still in the vadose zone are present at each of the productive sites in the Djadokhta Formation (Loope et al. 1998). Earlier workers believed the animals were buried alive by drifting sand during violent wind storms (Jerzykiewicz et al. 1993), but although they are found adjacent to dune deposits, none of the fossils collected at Ukhaa Tolgod was recovered from sediment that is demonstrably windblown (Loope et al. 1998). The fossil-bearing sandstones are structureless, lacking the distinctive stratification of eolian deposits. Mass wasting events, however, commonly produce structureless depos-

\footnotetext{
Received May 12, 1999; accepted August 4, 1999.

${ }^{1}$ Conservation and Survey Division, University of Nebraska, Lincoln, Nebraska 68588-0517, U.S.A.

${ }^{2}$ Department of Vertebrate Paleontology, American Museum of Natural History, Central Park West at 79th Street, New York, New York 10024-5192, U.S.A.
}

its. At Ukhaa Tolgod, structureless sandstones that are present between thick single sets of cross-strata were deposited in interdune areas (fig. 2). Some bodies of structureless sandstones lie laterally adjacent to cross-strata (figs. 3, 4), and we interpret these as alluvial fan deposits (fig. 2). Here our calculations and numerical model show that during heavy rainstorms, the early-emplaced, slope-parallel calcitic zones within dunes allowed sufficient pore water pressure to develop within the uppermost $50 \mathrm{~cm}$ of sand to trigger translational slides. During sliding, the sand was transformed into a viscous fluid that accelerated down the long, steep lee slopes and buried animals in its path.

Many human lives are lost each year when water saturates fragmental materials that underlie steep slopes and triggers rapid mass movements. The steep lee slopes of large sand dunes, however, are not deemed dangerous because (1) water drains rapidly from well-sorted sand and (2) torrential rainfall events are rare in desert settings. When a sandy bedform migrates, the upper part of its lee slope is steepened by the accumulation of grains until a critical angle is reached $\left(\theta_{c}\right)$ and loose sand avalanches down that slope, coming to rest at a lower, residual angle $\left(\theta_{\mathrm{r}}\right)$. In eolian dunes composed of fine sand, $\theta_{c}=35^{\circ}$ and $\theta_{\mathrm{r}}=31^{\circ}$ (Carrigy 1970). Any rain that is not evaporated or transpired by dune plants has the potential to move downward through a 


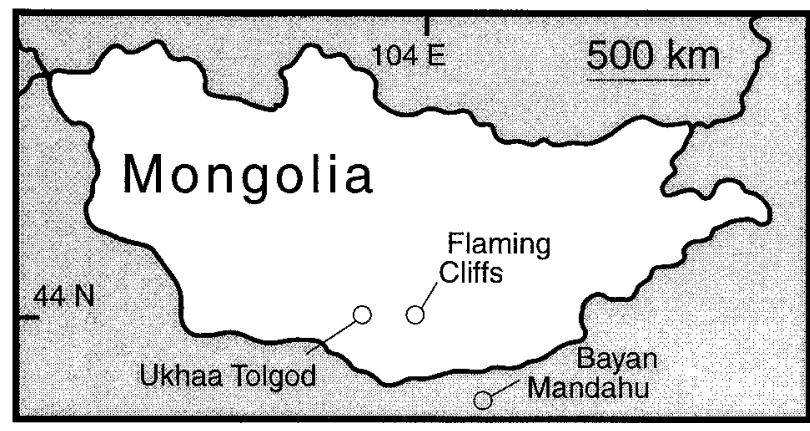

Figure 1. Locations of the three sites discussed in text

thick unsaturated zone and eventually recharge the water table, which, because of the high saturated hydraulic conductivity $\left(K_{\text {sat }}\right)$ of dune sand, is nearly flat and rarely much higher than the level of interdune flats. We argue here, however, that with time, infiltrating rainwater can alter the hydrologic properties of very slowly migrating or temporarily stabilized dunes; during rare storm events, these alterations can lead to perched water tables, destabilization of the lee slopes, and to the generation of rapid (and lethal) mass movements.

\section{Pedogenesis beneath Dune Lee Slopes}

In semiarid to arid settings, because there may be relatively little recharge of rainwater to the regional water table, evaporation or transpiration from the unsaturated zone leads to saturation for salts, and early precipitates (especially gypsum and calcite) can be emplaced in the lower part of the zone that is frequently wetted (Gile et al. 1981). Cross-strata with abundant intergranular calcite are prominent within friable eolian sandstones of the Djadokhta Formation at both of the richly fossiliferous sites where we have conducted field studies-Ukhaa Tolgod and Flaming Cliffs (fig. 1). At Flaming Cliffs, calcitic rhizoliths are present in the calcitic zones and are oriented parallel to the foresets (Loope and Dingus 1999). Identical rhizoliths and calcitic zones have been described from correlative, fossiliferous rocks at Bayun Mandahu, $500 \mathrm{~km}$ to the southeast (Jerzykiewicz et al. 1993). At Ukhaa Tolgod, rhizoliths are generally absent, and cylindrical burrows filled with calcite-free dune sand are distinct within the calcite-rich sandstones (Loope et al. 1998, fig. 3d). Although the texture of eolian cross-strata at Ukhaa Tolgod ranges from coarse sand to very fine sand, only the fine and very fine strata are calcitic (fig. 5). Figure 3 shows four calcitic zones that are $5-10 \mathrm{~cm}$ thick and spaced at 1-2-m intervals within a 25-m-thick set of dune cross-strata. Because burrows crosscut (and therefore postdate) the calcitic zones, Loope et al. (1998) interpreted the calcite as a pedogenic precipitate. The presence of burrows and the absence of fractures and laminar fabrics suggest that strong induration (as in petrocalcic horizons) did not take place. Because there is no apparent source within the parent sand, the calcium was likely derived from the atmosphere (Gile et al. 1981). Because atmospheric delivery of calcium is a relatively slow process-accumulation rates calculated from Quaternary soils in the western United States range from 0.1 to $51 \mathrm{~g} \mathrm{~m}^{-2} \mathrm{yr}^{-1}$ (Machette 1985; Reheis et al. 1995/-these early, vadose precipitates indicate that during episodes of calcite accumulation, dunes could have been stabilized for thousands, if not tens of thousands of years.

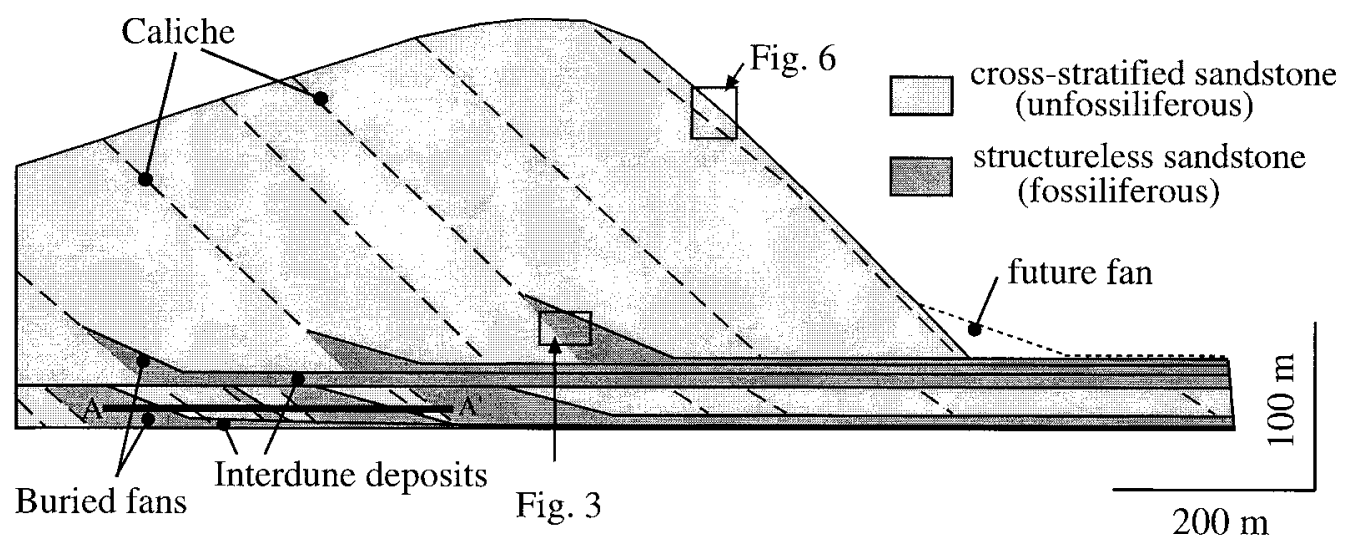

Figure 2. Interpretive diagram of dune, interdune, and alluvial fan deposits of the Djadokhta Formation. Lateral sequence of facies shown along transect $A-A^{\prime}$ was based on mapping (see fig. 4). 


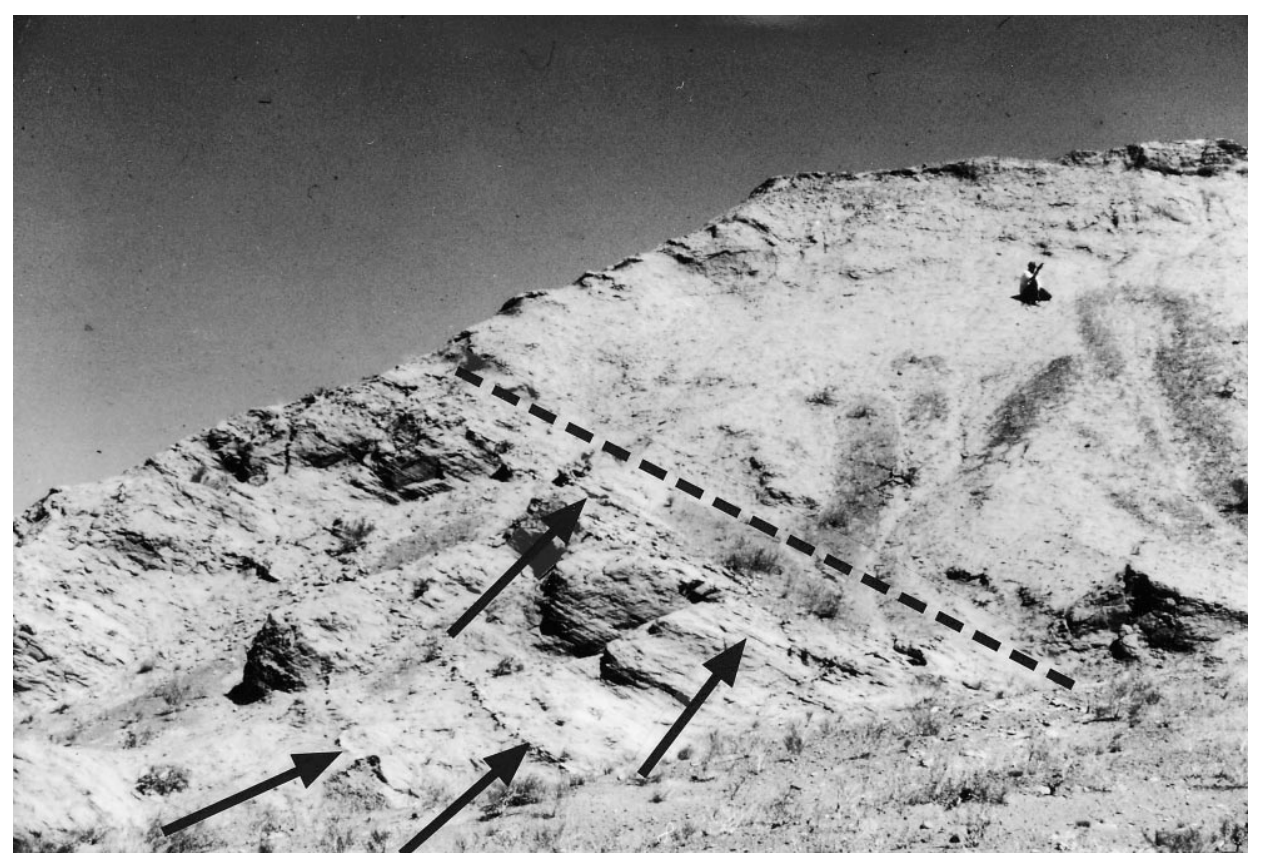

Figure 3. Contact (dashed line) between unfossiliferous eolian cross-strata on left and structureless, fossil-rich facies on right (man sits at position of in situ fossil mammal skeleton). Exposed thickness of the set of cross-strata on left is $24 \mathrm{~m}$. Arrows show positions of four calcitic zones, each of which formed at shallow depth $(<1 \mathrm{~m})$ beneath the dune lee face.

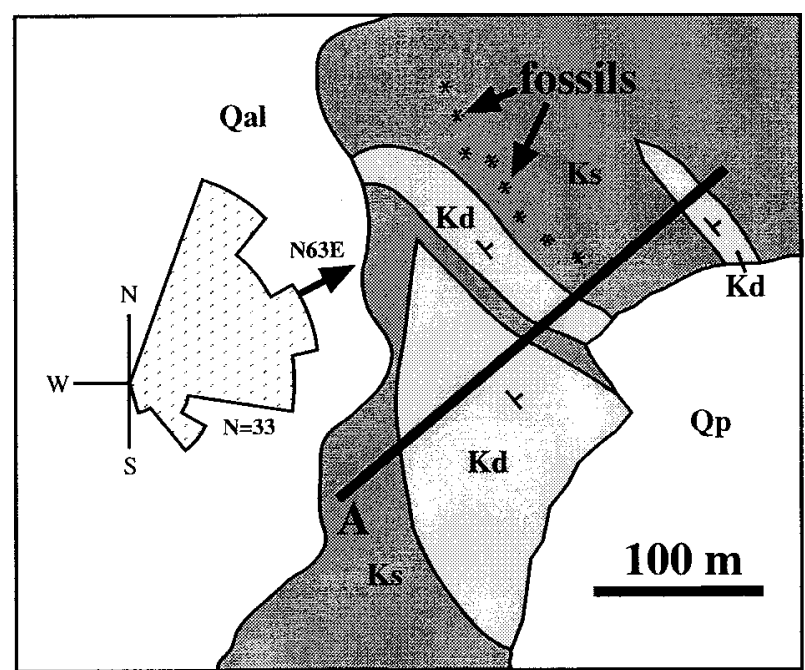

Figure 4. Map showing distribution of cross-stratified and structureless sandstone bodies and vertebrate fossils in the Djadokhta Formation in the eastern portion of Ukhaa Tolgod. Field mapping was based on aerial photographs. Cross section $A-A^{\prime}$ (see fig. 2) is parallel to dip of mapped cross-strata and subparallel to the resultant vector from all paleocurrent data collected at Ukhaa Tolgod.
The dip-parallel orientation of the rhizoliths at Flaming Cliffs is further evidence for a vadose origin for the calcitic zones (Loope and Dingus 1999). In the vadose zone, roots growing preferentially within tightly packed foresets would exploit water more efficiently than roots growing at high angles to stratification because the tightly packed zones would retain more water after initial gravitational drainage (Hillel 1980). In a water-saturated medium, there would be little advantage to root elongation parallel to bedding.

The abundance of fine to very fine sand in the Cretaceous dunes enhanced the likelihood of pedogenic calcite accumulation. Hydrologic studies in central Saudi Arabia (Dincer et al. 1974) have shown that, on dunes composed of medium sand, a significant portion (ca. $25 \%$ ) of the $80-\mathrm{mm}$ rainfall moves through the active dunes and recharges groundwater. In fine-grained dunes, however, no recharge takes place because the rate of infiltration is slower and evaporation is enhanced (Dincer et al. 1974). Flow within the unsaturated zone is strongly influenced by slope-parallel heterogeneities, particularly when infiltrated water is redistributed by unsaturated flow after infiltration ceases (Stephens 1996). Field experiments on a sand dune by McCord et al. (1991) demonstrated the very 


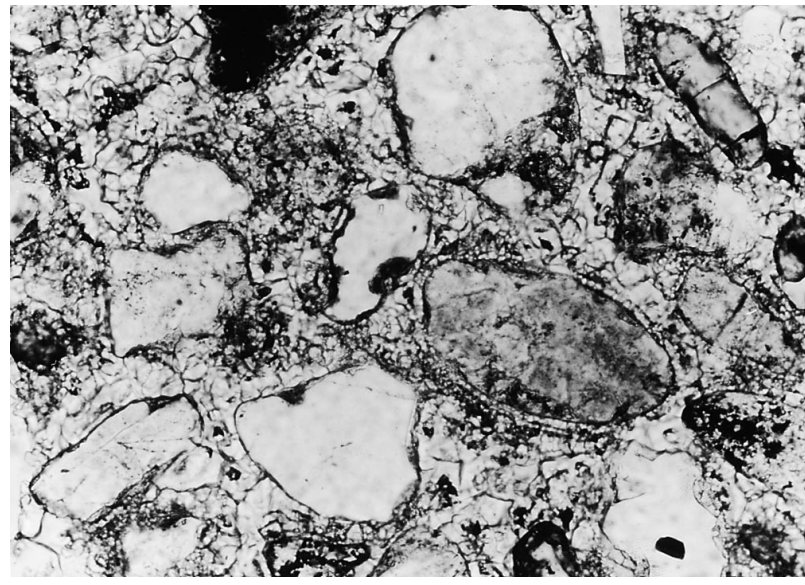

Figure 5. Photomicrograph of fine-grained eolian sandstone with intergranular calcite, interpreted as caliche. Calcite crystals are $10-30 \mu \mathrm{m}$ in diameter. Field of view is $1.25 \mathrm{~mm}$ wide.

strong tendency for infiltrated rainwater to be redistributed laterally, parallel to stratification, rather than vertically downward into the dune. Thus, the slope-parallel bedding in dune sand is a major control on the distribution of vadose precipitates, preventing deep redistribution of rainwater and maintaining abrupt upper and lower boundaries. In contrast to saturated flow in porous media, unsaturated flow occurs preferentially in finergrained or more tightly packed zones (Stephens 1996). Within the dunes at White Sands, New Mexico, Schenk and Fryberger (1988) showed that gypsum cement accumulates far above the water table within distinct zones composed of tightly packed wind-ripple deposits but not in adjacent foresets composed of more loosely packed avalanched sand. As in our Cretaceous eolian sandstones, dune interiors at White Sands are composed of alternating, sharply defined packages of early cemented and uncemented foresets. Similar patterns of early cementation have been described from calcareous eolianites (Pye and Tsoar 1990).

The calcitic zones dictate that the long-term climate of the stabilized dune field was dominated by light rainfall events that did not penetrate more than the uppermost meter of dune sand. Because of very low rates of unsaturated flow and water vapor diffusion upward through the dry sand near the dune surface, water that reached greater depths would not be evaporated and would leach the calcium to the water table (Dincer et al. 1974). After the calcitic zones were emplaced, the generation of lethal mass movements had to await the arrival of a rainfall event capable of saturating a substantial portion of the material above the zones.

\section{Instability of Water-Saturated Sand on Dune Slopes}

Many slope failures are the result of buildup of water in the regolith when infiltration at the surface takes place at a greater rate than deep percolation (Campbell 1975). Positive pore water pressure develops above a slope-parallel subsurface zone with low permeability, thereby reducing the effective shear strength of the regolith and allowing a translational slope failure (fig. 6). Calcite precipitation within dune sands in the Djadokhta Formation resulted in large reductions in porosity and in the predominant size of the remaining pores (fig. 5). Based on theoretical and empirical models in which $K_{\text {sat }}$ is proportional to the third or fourth power of porosity and is inversely proportional to pore radius (Hillel 1980; Rawls et al. 1992), it is reasonable to assume that calcite precipitation reduced the $K_{\text {sat }}$ of the dune sand by one or more orders of magnitude.

We used standard slope stability formulae (Graham 1984) to calculate the pore water pressure required to produce failure of cohesionless sand on a $31^{\circ}$ dune lee slope and a computer program to model the distribution of pore water pressure within sand underlain by a calcitic zone during rainstorms of varying intensity and duration. The critical pore pressure for failure of cohesionless sand on a $31^{\circ}$ slope was calculated using a standard infinite slope analysis (Graham 1984), with the friction strength of the sand represented by $\phi=35^{\circ}$ (Carrigy 1970). We then used a saturated/unsaturated flow model (SWMS_2D; Simunek et al. 1994) to simulate one-dimensional steady infiltration of water into a layer of clean fine sand overlying calcitic sand, to identify the duration required to achieve the critical pore pressure at a given infiltration rate. We assume that all rainfall infiltrates because of the high $K_{\text {sat }}$ of the surficial sand. Porosity was set at 0.35 for the clean dune sand and 0.10 for the calcitic zone. The sand is initially dry ( $2 \%$ water by volume). Other flow model parameters have much less impact on the results and were estimated from measurements on fine sands reported in an extensive digital database (Leij et al. 1996).

The assumption of vertical one-dimensional flow is a reasonable approximation for the time periods that we simulated. Before the wetting front reaches the calcitic zone, the potential gradient vertically downward into the dry sand is much greater than 


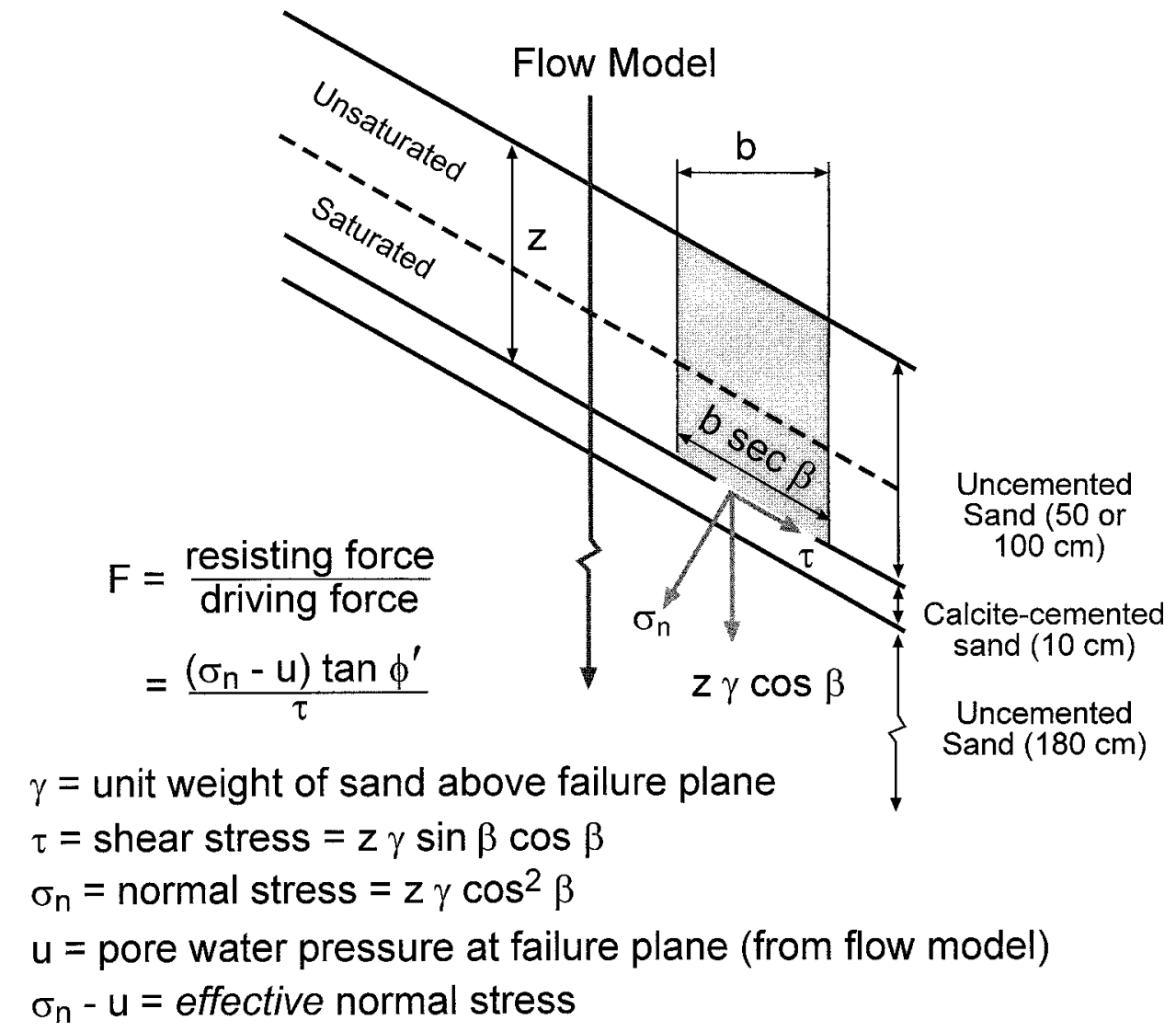

Figure 6. Slope stability calculation, using the infinite slope method (Graham 1984), combined with a numerical water flow model. The factor of safety $(F)$ represents the balance between forces driving and resisting failure and is calculated for an effectively infinite planar failure surface at the top of a slope-parallel calcitic zone. The infinite slope approach is generally regarded as a reasonable approximation for shallow planar failures on long slopes (Graham 1984). At failure, $F=1$. Driving and resisting forces are calculated for the base of a block of material above the failure plane, of downslope width $b$ and unit cross-slope width. The driving force is simply the slope-parallel shear stress generated by the weight of this block. The resisting force is the frictional strength generated at the failure plane, which is a function of the effective normal stress $\left(\sigma_{n}-u\right)$ and the frictional strength parameter tan $\phi^{\prime}$. The sand at the failure plane is assumed to have negligible cohesive strength. The effective normal stress reflects the offsetting effects of pore water pressure $(u)$ and the stress normal to the failure plane that is generated by the weight of the block $\left(\sigma_{n}\right)$. As pore water pressure increases, effective normal stress and frictional strength are reduced. The pore water pressure at the failure plane is calculated numerically by the water flow model, represented by the vertical arrow. Flow is calculated for $180 \mathrm{~cm}$ of sand beneath the calcitic zone to avoid lower boundary effects on the results.

the slope gradient. After the wetting front reaches the calcitic zone, positive pore pressures develop much more rapidly than any significant lateral drainage can occur down a long dune slope (Barling et al. 1994). The model assumes homogeneous sand above the calcitic layer and thus does not represent the slope-parallel stratification that we suggest had a strong influence on the initial development of calcitic layers. In this case, however, we are simulating rapid infiltration rather than redistribution following rainfall. During rapid infiltration, a boundary marked by a small but abrupt change in grain size or packing might briefly slow the penetration of the wetting front, but this effect would not persist because the influx of water from above would rapidly increase the potential gradient across the boundary. The model also does not represent the "finger flow" phenomenon often observed in dry, apparently homogeneous sandy soils, in which infiltration occurs preferentially in narrow vertical fingers rather than in a uniform wetting front (e.g., Ritsema et al. 1998). We assume that a continuous saturated zone will develop above the impeding calcitic layer even if infiltration initially occurs 


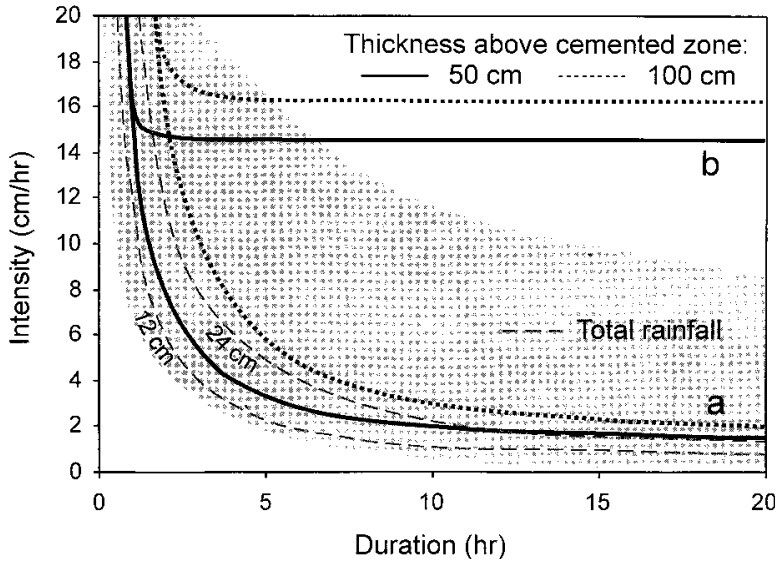

Figure 7. Thresholds for failure of dune sand as a function of rainfall duration and average intensity, based on a standard slope stability analysis and numerical modeling of infiltration. The heavy solid and dotted lines labeled $(a)$ represent the thresholds for two thicknesses of sand with $K_{\text {sat }}=36 \mathrm{~cm} \mathrm{~h}^{-1}$ above a calcitic zone with $K_{\text {sat }}=0.36 \mathrm{~cm} \mathrm{~h}^{-1}$ (i.e., a $K_{\text {sat }}$ reduction of two orders of magnitude due to calcite precipitation); lines labeled $(b)$ represent thresholds if calcite accumulation reduces $K_{\text {sat }}$ by only one order of magnitude $\left(36-3.6 \mathrm{~cm} \mathrm{~h}^{-1}\right)$. The form of these modeled thresholds resembles empirically determined precipitation thresholds for slope failure (Cannon 1988). The threshold lines become more vertical and converge on the left side of the graph, reflecting the near-constant minimum times required for the wetting front to reach the calcitic zone at either 50 or $100 \mathrm{~cm}$ depth. The lines become near-horizontal on the right side of the graph as the threshold intensity approaches the maximum steady flow rate through the calcitic zone. The gray area represents an envelope of rare but plausible rainfall events. The lower bound of this envelope is set at intensity-duration combinations with a 100-yr recurrence interval in the west-central Great Plains of the United States, representative of cool, dry continental interiors (Hershfield 1961). The upper bound is the global limit for observed intensity-duration combinations (van der Leeden et al. 1990).

through finger flow; in fact, in some cases, finger flow might allow more rapid saturation immediately above the calcitic zone than is simulated by the model.

We found that pore pressure sufficient for failure can develop under combinations of intensity and duration that are rare but plausible, based on modern observations (fig. 7). For example, $25 \mathrm{~cm}$ of rainfall in $6 \mathrm{~h}$-as in the Rapid City, South Dakota, flood of 1972 (Johnson 1973) —would trigger failure of a 50-cm layer of sand above the calcitic zone, if calcite precipitation had reduced $K_{\text {sat }}$ by two orders of magnitude (fig.7). The presence of crocodiles in the Djadokhta Formation (Lefeld 1971) indicates that, in contrast to the situation in modern continental interiors, subfreezing temperatures did not occur at $45^{\circ} \mathrm{N}$ in the central core of Asia during the Late Cretaceous (Barron and Washington 1982). Higher air temperatures during this time period may have allowed more moisture to reach highlatitude continental interiors.

\section{Conclusions}

We conclude that during heavy rainfall events, perched water tables developed on the tops of shallow calcitic zones that underlay dune lee slopes, generating translational slides. These slides transformed into fast-moving sediment gravity flows that overwhelmed animals on dune slopes and between dunes. The pedogenic calcite indicates that the fossilized animals occupied the area during semiarid intervals and that dunes were immobile for thousands to tens of thousands of years. Because the thickness of preserved cross-strata typically represents a small percentage of the original dune height (Rubin and Hunter 1982), the Cretaceous dunes were probably at least $100 \mathrm{~m}$ high and may have been higher than $250 \mathrm{~m}$; thus, a single slope failure could produce a flow depositing a large volume of sediment at the foot of the dune. Rare, heavy rainfall events were the trigger for preservation of the numerous and extraordinarily wellpreserved fossils of the Diadokhta Formation. Two preconditions that are rarely met in subsiding sedimentary basins were also required: (1) steeply sloping, high-relief topographic elements (provided here by large eolian dunes that grew and migrated during arid intervals) and (2) shallow, slope-parallel barriers to the infiltration of rainwater (provided by pedogenic calcite emplaced during wetter episodes when dunes were immobile).

\section{A C K N O W L E D G M E N T S}

We thank D. Dashzeveg, M. Novacek, M. Norell, C. Swisher, A. Davidson, L. Chiappe, G. Rougier, I. Horowitz, J. Clark, A. Freeze, and K. Dewey. Funds were provided by the American Museum of Natural History and the Infoquest Foundation. 


\section{R E F E R E N C E S C I T E D}

Barling, R. D.; Moore, I. D.; and Grayson, R. B. 1994. A quasi-dynamic wetness index for characterizing the spatial distribution of zones of surface saturation and soil water content. Water Resour. Res. 30:1029-1044.

Barron, E. J., and Washington, W. M. 1982. Cretaceous climate: a comparison of atmospheric simulations with the geologic record. Palaeogeogr. Palaeoclimatol. Palaeoecol. 40:103-133.

Campbell, R. H. 1975. Soil slips, debris flows, and rainstorms in the Santa Monica Mountains and vicinity, Southern California. U.S. Geol. Surv. Prof. Pap. 851, $51 \mathrm{p}$.

Cannon, S. H. 1988. Regional rainfall-threshold conditions for abundant debris flow activity. In Ellen, S. D., and Wieczorek, G. F., eds. Landslides, floods, and marine effects of the storm of January 3-5, 1982, in the San Francisco Bay Region, California. U.S. Geol. Surv. Prof. Pap. 1434, 310 p.

Carrigy, M. A. 1970. Experiments on the angles of repose of granular materials. Sedimentology 14:147-158.

Dashzeveg, D.; Novacek, M. J.; Norell, M. A.; Clark, J. M.; Chiappe, L. M.; Davidson, A.; McKenna, M. C.; Dingus, L.; Swisher, C; and Altangerel, P. 1995. Extraordinary preservation in a new vertebrate assemblage from the Late Cretaceous of Mongolia. Nature 374:446-449.

Dincer, T.; Al-Mugrin, A; and Zimmerman, U. 1974. Study of the infiltration and recharge through the sand dunes in arid zones with special reference to the stable isotopes and thermonuclear tritium. J. Hydrol. 23: 79-109.

Gile, L. H.; Hawley, J. W.; and Grossman, R. B. 1981. Soils and geomorphology in the Basin and Range area of southern New Mexico-guidebook to the Desert Project. N.M. Bur. Mines Miner. Resour., Mem. 39, $222 \mathrm{p}$.

Graham, J. 1984. Methods of stability analysis. In Brunsden, D., and Prior, D. B., eds. Slope instability. Chichester, Wiley, p. 171-215.

Hershfield, D. M. 1961. Rainfall frequency atlas of the United States. U.S. Weather Bur. Tech. Pap. 40.

Hillel, D. 1980. Fundamentals of soil physics. San Diego, Calif., Academic Press.

Jerzykiewicz, T.; Currie, P. J.; Eberth, D. A.; Johnson, P. A.; Koster, E. H.; and Zheng, J. 1993. Djadokhta Formation correlative strata in Chinese Inner Mongolia: an overview of the stratigraphy, sedimentary geology, and paleontology and comparisons with the type locality in the pre-Altai Gobi. Can. J. Earth Sci. 30: 2180-2195.

Johnson, K. A. 1973. Meteorology and hydrology of Rapid City flood. Am. Soc. Civil Eng., Hydraulic Div., Spec. Conf. Proc. 21:451-455.

Lefeld, J. 1971. Geology of the Djadokhta Formation at Bayn Dzak (Mongolia). Palaeont. Pol. 25:101-127.
Leij, F. J.; Alves, W. J.; van Genuchten, M. Th.; and Williams, J. R. 1996. The UNSODA unsaturated soils database. User's Manual Version 1.0. EPA/600/R-96/095, National Risk Management Research Laboratory, U.S. Environmental Protection Agency, Cincinnati.

Loope, D. B., and Dingus, L. 1999. Mud-filled Ophiomorpha from Upper Cretaceous continental redbeds of Southern Mongolia: an ichnologic clue to the origin of detrital, grain-coating clays. Palaios 14:452-459.

Loope, D. B.; Dingus, L.; Swisher, C. C. III; and Minjin, C. 1998. Life and death in a Late Cretaceous dunefield, Nemegt Basin, Mongolia. Geology 26:27-30.

Machette, M. N. 1985. Calcic soils of the southwestern United States. In Weide, D. L., ed., Soils and Quaternary geomorphology of the southwestern United States. Geol. Soc. Am. Spec. Pap. 203:1-21.

McCord, J. T.; Stephens, D. B.; and Wilson, J. L. 1991. Hysteresis and state-dependent anisotropy in modeling unsaturated hillslope hydrologic processes. Water Resour. Res. 27:1501-1518.

Pye, K., and Tsoar, H. 1990. Aeolian sand and sand dunes. London, Unwin Hyman, 396 p.

Rawls, W. J.; Ahuja, L. R.; and Brakensiek, D. L. 1992. Estimating soil hydraulic properties from soils data. In M. Th. van Genuchten et al., eds. Indirect methods for estimating the hydraulic properties of unsaturated soils. Proc. Workshop. U.S. Soil Salinity Lab. and Dep. Soil and Envir. Sci., U. Calif., Riverside, p. 329-340.

Reheis, M. C.; Goodmacher, J. C.; Harden, J. W.; McFadden, L. D.; Rockwell, T. K.; Shroba, R. R.; Sowers, J. M.; and Taylor, E. M. 1995. Quaternary soils and dust deposition in southern Nevada and California. Geol. Soc. Am. Bull. 107:1003-1022.

Ritsema, C. J.; Dekker, L. W.; Nieber, J. L.; and Steenhuis, T. S. 1998. Modeling and field evidence of finger formation and finger recurrence in a water repellent sandy soil. Water Resour. Res. 34:555-567.

Rubin, D. M., and Hunter, R. E. 1982. Bedform climbing in theory and in nature. Sedimentology 29:121-138.

Schenk, C. J., and Fryberger, S. G. 1988. Early diagenesis of eolian dune and interdune sands at White Sands, New Mexico. Sediment. Geol. 55:109-120.

Stephens, D. B. 1996. Vadose zone hydrology. Boca Raton, Fla., CRC, 347 p.

Simunek, J.; Vogel, T.; and van Genuchten, M. Th. 1994. The SWMS_2D code for simulating water flow and solute transport in two-dimensional variably saturated media. Version 1.2. Research Report 132, U.S. Salinity Laboratory, Agricultural Research Service, U.S.D.A., Riverside, Calif.

van der Leeden, F.; Troise, F. L.; and Todd, D. K. 1990. The water encyclopedia. Boca Raton, Fla., Lewis, p. 44. 